\title{
KAJIAN ESTETIK SIMBOLIK ADVERTORIAL (ABOVE THE LINE) PRODUK “MADURASE" DI TABLOID IND-JAMU, TABLOID AURA, DAN MAJALAH UMMAT
}

\author{
Pujiyanto \\ Program Studi Desain Komunikasi Visual Fakultas Sastra Universitas Negeri Malang \\ email : Anihr91@yahoo.com
}

\begin{abstract}
Abstrak
Media lini atas (above the line) merupakan media periklanan tidak langsung yang berbayar. Advertorial yang merupakan gabungan iklan dengan pemberitaan (editorial) adalah salah satu perangkat media lini atas. Ini merupakan iklan berbayar yang disusun dengan menggunakan bentuk pemberitaan. Singkat kata, ini adalah penyampaian pesan secara tidak langsung tentang produk dan merek tertentu kepada khalayak melalui media massa. Artikel ini mengkaji aspek estetik simbolik advertorial produk "Madurasa" yang diterbitkan media cetak nasional. Tiga sampel advertorial yang diteliti dimuat di tiga media cetak nasional yang berbeda, yakni tabloid Ind-Jamu, tabloid Aura, dan majalah Ummat. Dimensi estetik simbolik advertorial tersebut disajikan lewat isi berita, tipografi, gambar, dan tata letak perwajahan. Hal tersebut merupakan media komunikasi verbal dan visual sebagai kegiatan aktifitas promosi merek dan produk agar dapat diterima konsumen. Setelah data dikumpulkan lewat observasi, wawancara, dan dokumen, penelitian ini menemukan bahwa advertorial tersebut menggunakan pendekatan estetik simbolik yang ditunjukkan dengan menghubungkan serta mendekatkan produk dan merek "Madurasa" dengan aspek sosio kultural khalayak sebagai calon pengguna. Dengan demikian, advertorial media lini atas (above the line) merupakan karya komunikasi visual yang estetik melalui simbol-simbol sebagai ramuan citra produk dan merek agar dapat diterima khalayak
\end{abstract}

Kata kunci: Estetika Desain, Simbol, Above The Line, Madurasa

\begin{abstract}
Above the line advertisement is an indirect paid advertising. Advertorial which is an advertisement designed in the news report fashion is an example of the above the line promotion tool. Thus, it is a paid ads fashioned in such way to look like a news story. To put it in another way, it is presenting as well as delivering an implicit message on certain product dan brand to a broader audience through mass media. The paper attempts to describe eshetic and symbolic dimension of 'Madurasa" advertorial placed at the national print media. Three advertorial sample published at three highly segmented tabloid and magazine, namely Ind-Jamu, Aura, and Ummat magazine has been selected. The esthetic symbolic of the advertorial has been well displayed through the content of the news story, along with its typography, its picture and its layout. This represents verbal as well as visual communication means designed to promote and persuade the audiences to agree to take the advertised product and brand. After collecting data by means of observation, interview and document inquiry, this research found that the 'Madurasa' advertorial has employed esthetic symbolic tools in designing its content. Interestingly, in doing so, it tries to make the product closer to its audiences socially and culturally. In addition, it constructs the mesaages in a such way so as to suit to its social and cultural needs of the audiences. To sum up, the 'Madurasa' advertorial is an esthetic visual communication utilizing various symbols which are blended in such way so as to have the audience agree to take the advertised product and brand
\end{abstract} Keywords: design aesthetic, symbol, above the line, Madurasa

Periklanan (advertisement) adalah suatu

proses komunikasi massa yang melibatkan 
sponsor tertentu, yaitu advertiser yang membayar jasa ke media massa atas penyiaran atau terbitnya iklan. Adapun iklannya itu sendiri biasanya dibuat atas pesanan si pemasang iklan, oleh sebuah agen atau biro iklan; atau bisa saja oleh bagian Humas (Public Relations) lembaga pemasang iklan itu sendiri (Suhandang, 2005:13). Periklanan merupakan sarana penyampaian pesan suatu produk atau jasa dari pengirim pesan yaitu perusahaan ke penerima pesan yaitu masyarakat yang bersifat "statis maupun dinamis" agar masyarakat terpancing, tertarik, tergugah untuk menyetujui, dan mengikuti. Dalam penyampaian pesan secara tidak langsung ini, dipublikasikan melalui media massa atau media lain yang bisa terbaca oleh masyarakat sehingga mendapatkan reaksi dan aksi yang positif. Pendapat tersebut menegaskan bahwa dalam periklanan terjadi proses komunikasi pemasaran tak langsung tentang sebuah penawaran produk yang ditujukan pada masyarakat. J Thomas Russell dan W Ronald Lane (1992:52), menggaris bawahi agar komunikasi pemasaran dalam periklanan berjalan secara efektif harus memperhatikan dua tingkatan, yaitu: (1) mengkomunikasikan dan (2) pelaksanaan tujuan pemasaran.

Agar masyarakat mengenal, tertarik, mempunyai keinginan, memilik keyakinan, dan melakukan tindakan untuk membeli suatu produk, maka pihak biro advertising bekerjasama dengan media massa untuk menerbitkan iklan. Secara umum, media periklanan menurut Frank Jefkins (1997:86,136) terbagi menjadi dua, yaitu above the line (media lini atas) dan below the line (media lini bawah). Jenis media komunikasi yang termasuk media lini atas atau above the line (ATL) adalah berbagai media yang diinformasikan dan dikomunikasikan melalui berita berupa advertorial di media massa seperti surat kabar, televisi, radio, dan internet. Advertorial melalui ATL merupakan komunikasi non individu tentang produk maupun jasa dengan sejumlah biaya, melalui berbagai media massa yang dilakukan oleh perusahaan. Freddy Rangkuti (2007:162), menyatakan bah-wa ATL merupakan jenis iklan yang mengharuskan pembayaran komisi kepada biro iklan, bila iklannya dimuat di media massa cetak. Dalam prakteknya, ATL ini bersifat sewa ruang bila iklan tersebut hendak diterbitkan. Adapun ATL yang mengarah ke media cetak adalah media yang dipasang atau dikomunikasikan di melalui media massa yang membayar pada pihak media massa, seperti koran, tabloid, majalah, dan buku. Media ATL merupakan iklan yang diterbitkan di media masa ini sifatnya sesaat, seperti advertorial yang muncul pada waktu-waktu tertentu, sesuai permintaan pemesan atau sesuai perjanjian. Agar advertorial yang diterbitkan di media ATL dapat diterima khalayak maka perlu memperhatikan estetika.

Advertiser sebagai kreator ad-vertorial dipengaruhi oleh berbagai hal. Dalam penciptaan advertorial tidak lepas dari target market dan khalayak yang berhubungan dengan bisnis. Jhon Wistrand dan Kranz (1974:119) menyatakan bahwa perusahaan meru-pakan organisasi yang kompleks, dari bagian produksi, bagian pemasaran, bagian desain, dan lain-lain. Bagianbagian tersebut saling mengisi dan berperan untuk menetapkan kualitas estetik desain yang diciptakannya, meskipun kualitas estetik yang dite-tapkan selalu mempunyai keterbatasan waktu untuk kebutuhan bisnis. Mereka berkata bahwa bekerja di industri merupakan keadaan yang tidak menguntungkan karena dihadapkan pada banyak masalah, yaitu di satu sisi cenderung pada masalah bisnis dan sisi lain harus memikirkan masalah estetik. Penciptaan karya desain di sini dipengaruhi oleh masalah pasar.

Antara masalah bisnis dan masalah estetika desain dalam industri tidak dapat dipisahkan karena terikat suatu hubungan yang saling mengisi dan membutuhkan. Suatu karya desain media periklanan dapat dikatakan berhasil bila dapat diterima masyarakat berdasarkan berbagai aspek seperti fungsi, ekonomi, dan dampaknya terhadap manusia. Dilihat dari sudut ekonomi, desain periklanan dibuat untuk memenuhi permintaan pasar berdasar-kan tingkat khusus dari harga produk yang dipasarkan (Beakley, 1974:369-370). Dalam hal ini W.F. 
Haung menyebutnya sebagai "estetik komoditi" (commodity aesthetics), yaitu estetik yang diciptakan berdasarkan motif daya tarik, keterpesonaan (eye catching), dan perhatian massa konsumen semata (Piliang: http;//pr.qiandra.net.id). Agar peran advertiser ikut andil dalam menciptakan periklanan, estetika tidak hanya sesuai untuk konsumen semata, tetapi juga ada pengontrolan makna yang disampaikan dalam bentuk media tersebut (Frascara, 2004:74).

Advertorial merupakan hasil budaya serta sebagai alat komunikasi melalui proses interaksi menggunakan simbol-simbol yang dipahami maknanya melalui proses belajar. Tindakan seseorang dalam proses interaksi melalui proses belajar dalam memahami simbol-simbol dan saling menyesuaikan makna dari simbol-simbol itu. Pemahaman simbol-simbol itu bukan sematamata merupakan suatu tanggapan yang bersifat langsung terhadap stimulus yang datang dari lingkungannya atau dari luar dirinya. Manusia mempunyai kemampuan bebas untuk berpikir untuk menentukan tujuan yang hendak dicapainya meskipun dibatasi oleh norma-norma, nilai-nilai sosial, dan makna simbol-simbol itu (Ritzer, 2009:58-59).

Agar interaksi antar kelompok dapat berjalan lancar, tentu kedua kelompok harus mengetahui simbol-simbol yang diterapkan pada wilayah tertentu. Seperti yang dikatakan Irwan Abdullah (2010:21), sesungguhnya kebudayaan itu memiliki batas wilayah di mana sekelompok orang mencari makna atas simbol-simbol. Budaya yang bersifat generik mengantar tingkah laku melalui simbol-simbol yang akan dimaknai dengan analisis konteks di mana simbol itu dibangun. Lebih lanjut Geertz (1983: 5) menyatakan bahwa untuk memahami suatu kebudayaan, aspek makna dan simbol lebih penting daripada tingkah laku manusia. Agar dapat memahami makna suatu kebudayaan, seseorang harus mampu menafsirkan simbolsimbol yang dipergunakan oleh orang lain (Poerwanto, 2000:58-59). Teori tersebut sama dalam buku Abangan, Santri, Priyayi dalam Masyarakat Jawa, bahwa simbol merupakan ekspresi yang tersimpan berbagai makna berupa gagasan ataupun pengalaman yang saling dapat memahami dan menghayati (Geertz, 1983:5).

Simbol-simbol pada objek-objek yang memiliki makna ditafsirkan melalui proses interaksi yang disampaikan kepada pihak lain. Interaksi antar individu melalui simbol-simbol yang saling berusaha memahami maksud dari tindakan masing-masing lantas diinterpretasikan sehingga pesan dapat diterima (Nazsir, 2009:32). Tindakan dan interaksi manusia bukan suatu proses mental yang terisolasi menciptakan makna dan simbol. Mereka mempelajarinya selama interaksi pada umumnya dan khususnya selama sosi-alisasi. Dalam interaksi simbolik, pokok perhatian utamanya bukanlah bagaimana orang secara mental menciptakan makna dan simbol, melainkan bagaimana mereka mempelajari hal tersebut selama interaksi pada umumnya dan khususnya selama sosialisasi (Ritzer \& Goodman, 2004: 294,394).

Advertorial di media ATL "Madurasa" oleh PT Air Mancur merupakan media perantara penyampai pesan dari pengirim (produsen) kepada penerima (konsumen). Media yang digunakan merupakan media yang berupa simbolsimbol yang dapat diterima oleh masyarakat sebagai pesan. Manusia menciptakan simbolsimbol melalui gambar, warna, tulisan, dan sebagainya sebagai alat komunikasi untuk aktivitas kegiatannya, seperti dalam menjual produk dan merek. Agar produk dan merek dapat diterima masyarakat, maka diciptakanlah advertorial yang menggunakan pencitraan melalui simbol-simbol yang akrab di masyarakat.

\section{METODE}

Advertorial merupakan media sebagai penyampai pesan berupa berita dari pihak perusahaan kepada masyarakat. Berita yang disampaikan pada advertorial menggunakan pendekatan pencitraan melalui simbol-simbol yang akrab agar dapat diterima oleh masyarakat. Manusia sebagai pencipta simbol yang diwujudkan dalam karya advertorial tentunya memiliki estetik simbolik yang dihadirkan 
melalui isi berita, tipografi, gambar, dan tata letak perwajahan. Kesemuanya itu merupakan media komunikasi verbal dan visual sebagai kegiatan aktifitas promosi merek dan produk agar dapat diterima konsumen.

Pengumpulan data dilakukan dengan menggunakan teknik observasi, wawancara, dan dokumen. Observasi bersifat terbuka yang semata-mata sebagai pengamat. Pengamatan dengan cara tak terstruktur yang dilakukan di lapangan, dengan pengamatan terbuka dan saling mengenal. Observasi dilakukan dengan pengamatan langsung pada berbagai media yang menerbitkan advertorial. Observasi untuk mengeta-hui sejauhmana estetika desain media promosi cetak advertorial yang mempunyai tekstual dan kontekstual. Wawancara yang digunakan adalah wawancara terstruktur yang menggunakan pedoman wawancara. Teknik ini mengacu pada situasi ketika seseorang peneliti melontarkan sederet pertanyaan yang lebih terarah. Informan dalam wawancara adalah pimpinan perusahaan, advertiser, dan ahli media untuk mengetahui estetika advertorial "Madurasa" PT Air Mancur Indonesia. Data dokumen menggunakan data primer yang diperoleh dari arsip di lingkungan PT Air Mancur.

Analisis penelitian menggunakan estetik simbolik dari Peirce. Menurut Peirce, bahwa simbol sebagai tanda yang dibagi menjadi tiga berdasarkan relasi di antara representasi dan objeknya, yaitu ikon, indeks, dan simbol (Noth,1990:44-45). Pengujian analisis dengan menggunakan metode trianggulasi data, yaitu penggabungan berbagai data yang saling mengisi, sehingga data benar-benar valid dan objektif. Trianggulasi data dengan cara: (a) membandingkan data hasil wawan-cara, observasi, dan dokumen, (b) membandingkan pengakuan informan secara pribadi dengan pernyataan kelembagaan (perusahaan), (c) membandingkan pendapat pada saat penelitian dengan situasi yang pernah terjadi sepanjang sejarah, (d) membandingkan pendapat antara advertiser, pimpinan perusahaan, dan ahli media.

\section{HASIL DAN PEMBAHASAN}

Iklan berarti pesan yang menawarkan suatu produk yang ditujukan kepada masyarakat melalui suatu media (Kasali,1995:9). Iklan merupakan media informasi yang dibuat sedemikian rupa agar dapat menarik minat khalayak, yang memiliki karakteristik tertentu dan persuasif sehingga para konsumen atau khalayak secara suka rela terdorong untuk melakukan sesuatu tindakan sesuai yang diinginkan pengiklan (Jefkins,1997:18). Advertorial adalah serangkaian komunikasi yang dipergunakan untuk menciptakan dan melihara hubungan menguntungkan diantara organisasi dan publiknya (Lee \& Johnson, 2007:16). Advertorial merupakan salah satu jenis iklan berbentuk berita bersifat persuasif yang disusun dan dirancang sesuai dengan karakter media massa, segmen pasar, kebutuhan dan selera masyarakat. Untuk membidik target market dan target khalayak yang sesuai, maka PT Air Mancur mengiklankan "Madurasa" di media massa cetak tertentu. Pemilihan media massa cetak tertentu dinggap mempunyai bidikan secara khusus sesuai dengan hobi pembaca.

\section{Tabloid Sebagai Sarana Publikasi}

Tabloid adalah jenis media massa yang mempunyai cici-ciri sebagai berikut: (1) Berbentuk lembaran-lembaran cetak berformat setengah lebar koran yang berisi berita, (2) Diterbitkan secara periodik dengan rentang waktu yang umumnya terbit mingguan, (3) Sedikit beritanya, tetapi luas dalam penyampainnya, (4) Komunikator media ini adalah lembaga, atau perusahaan, dan (5) Target market media ini sebagian kelompok masyarakat umum.

Dalam tampilannya, agar tabloid sampai bisa berkomunikasi dengan konsumen atau pembaca perlu di buat cover halaman depan yang menarik. Kepenarikan bisa ditempuh dengan jalan menonjolkan gambar, atau mempertegas judul berita yang menggugah penuh konotasi yang ditampilkan dengan cara memilih jenis huruf yang tepat, mempertebal huruf, atau tampilan warna yang menyolok pada halaman tersebut. 
Bagaimana agar pembaca tidak jenuh dan konsumen bisa membaca sambil lalu. Kondisi inilah yang menciptakan layout halaman tabloid dibuat sejumlah kolom. Blok-blok sejumlah kolom inilah yang mengantarkan konsumen bisa membaca sambil minum kopi. Dalam perwajahan perlu adanya perhatian serius khususnya dalam penempatan gambar, judul (headline), sub headline, warna maupun berita. Hadirnya publikasi yang dikemas dalam berita perlu juga memperhatikan rubrik atau menu dalam berita. Diharapkan berita yang sifatnya publikasi sebuah produk atau merek yang ditempatkan pada porsinya akan berdampak positif.

\section{Usaha Mencerdaskan Bangsa}

Publikasi perlu dilakukan bagi perusahaan, agar konsumen mengetahui informasi yang disampaikan, khususnya perkembangan perusahaan, merek, maupun produk. Sebagai contoh advertorial yang diterbitkan di tabloid IndJamu, yang beritanya mengenai lounching merek "Madurasa Superman". Advertorial yang diarahkan pada target khalayak ibu-ibu dan target market anak-anak khususnya yang kurang nafsu makan dan daya tahan tubuh rendah. "Madurasa Superman" sebagai penyelamat, agar anak-anak tetap sehat maka perlu ada minuman supleman berupa madu.

Pada advertorial di tabloid Ind-Jamu edisi 3 Maret 2007 berjudul "Usaha Superman mencerdaskan Bangsa". Judul berita yang ditulis menggunakan jenis huruf Times New Roman berwarna merah tua dan biru menghiasi pesan yang disampaikan. Ada dua kelompok kata maupun kalimat yang diinformasikan melalui pendekatan konotasi. Bila kalimat ini dijadikan dua, yaitu pertama tertulis "Superman" berwarna biru berukuran besar, yang menginformasikan bahwa "Superman" sebagai orang super, tokoh komik, pahlawan hereoistik, dan pahlawan yang suka menolong bagi yang membutuhkan. Kedua, kalimat yang tertulis "Usaha Mencerdaskan Bangsa”, merupakan kalimat yang terkandung "bagaimana cara mencerdaskan bangsa atau usaha agar bangsa bisa cerdas". Bila kalimat verbal pada judul "Usaha Superman Mencerdaskan Bangsa", bahwa Supermanlah yang bisa mencerdaskan bangsa. Apa itu Superman?. Superman ternyata produk madu dari PT Air Mancur bermerek "Madurasa Superman". Bila anak-anak Indonesia mengkonsumsi "Madurasa Superman" diharapkan bisa lebih cerdas.

Judul yang menarik di atas dipertegas oleh kalimat pada sub judul yang berbunyi "siapa yang tak kenal superhero asal USA, Superman, bahkan tokoh ini sudah familier di kalangan anakanak khususnya di Indonesia. Melalui ikon "Superman", PT. Air Mancur berupaya untuk turut mencerdaskan bangsa". Sub judul yang menggunakan jenis huruf Arial Bold Italic yang ditata rata kanan mem-berikan daya tarik untuk dibaca yang memberikan kesan santai dan akrab. Khalayak tentu ingin tahu lebih banyak, siapa Superman itu, ada apa, dan mengapa datang ke PT Air Mancur. Vektor S. Ringoringo selaku CEO PT Air Mancur menjelaskan bahwa produk merek "Madurasa Superman" merupakan hasil kerjasama Warner Bross Entertainment Inc. Hal ini merupakan salah satu langkah dalam upaya memenuhi standar Internasional. "Madurasa Superman" membidik anak-anak menjadi targetnya, produk untuk camilan sehat bagi anak Indonesia.

Sebagai penegas perkataan melalui advertorial ini maka ditampilkan wajah Vektor S. Ringoringo di sudut kiri atas. Ia memakai kaos yang warna dan logonya sama dengan yang dipakai Superman. Orang yang mempunyai wajah bersih, berkaca mata, dan rambut putih yang kesemuanya sebagai tanda orang penting di jajaran PT Air Mancur. Tidak mungkin orang biasa ditampilkan untuk mempromosikan "Madurasa Superman" pada tabloid ini. Vektor S. Ringoringo sangat bangga memakai kostum "Superman" sebagai tanda kebahagiaan, karena produk madu merek "Madurasa Superman" baru di lounching untuk dipasarkan ke masyarakat. Tampilnya orang penting tentu khalayak akan membaca berita ini.

Untuk mendukung berita loun-chingnya merek "Madurasa Superman" perlu didukung 
oleh warna sebagai memperkuat pesan. Warna pada baju Vektor S. Ringoringo yang didekatkan dengan kostum Superman yang berwarna biru dan merah, dan logo yang selalu melekat di dada Superman. Hadirnya properti ini mengingatkan kembali, seakan-akan Superman memang ada, datang ke PT Air Mancur untuk "Madurasa". Warna pada judul berita juga dipertegas dengan warna biru dan merah. Kesemuanya itu sengaja didekatkan agar khalayak teringat Superman pada waktu membaca berita. Adapun warna hitam pada berita yang ditampilkan pada ketiga kolom seluas setengah halaman, agar mudah dan enak dibaca yang memberi kesan tenang dan nyaman.

Agar advertorial menarik, enak dilihat, enak dibaca, maka penataan berita dibuat tiga kolom dan ditampilkan gambar orang setengah badan yang diletakkan di sebelah kiri atas. Di sebelah kanan gambar ditampilkan bahasa verbal berjudul "Usaha Superman Mencerdaskan Bangsa" yang ditempatkan di bagian atas kolom dua dan tiga. Gambar yang ditampilkan sebagai daya tarik pertama kali, baru mata khalayak diajak membaca judul, lalu sub judul, yang selanjutnya pada berita. Agar judul juga bisa berbicara maka diperlukan penekanan kata pada kalimat dalam judul seperti kata "Superman". Penegasan kata ini, untuk membidik masyarakat yang sebagian besar tahu tentang Superman, tokoh komik dari Amerika. Berita yang dibuat menjadi tiga kolom merupakan cara agar khalayak bisa membaca dengan santai, tidak lelah, dan mudah dibaca. Adapun kalimat dalam berita yang ditata rata kiri dan kanan yang memberi kesan rapi, teratur, santun, menarik, dan enak dipandang.

\section{Mengajak Sehat dan Hebat}

Tabloid Aura mempunyai segmentasi kaum Hawa, khususnya ibu-ibu. Melalui media cetak inilah "Madu-rasa Superman" dipublikasikan melalui advertorial. Berita "Madurasa Superman" hadir di tabloid Aura edisi 21-27 Februari 2007 yang berjudul "Sehat Dan Hebat Bersama Madurasa Superman". Judul yang menggunakan jenis huruf Arial warna hitam, yang memberi kesan tagas, jelas, dan komunikatif. Judul ini bila diperhatikan sangat menonjolkan "SUPERMAN" huruf Arial Bold Capital yang ukurannya lebih besar. Penegasan pada kata tersebut menggoda mata untuk melihat dan membacanya. Di samping itu, khalayak agar lebih cepat membaca judul yang begitu panjang, maka dipertegas melalui pemilihan kata yang dipertebal ukuran hurufnya, seperti "sehat hebat Madurasa Superman". Secara verbal melalui judul tersebut terjadi penegasan manfaat "Madurasa Superman". Bagi yang mengkonsumsi "Madurasa Superman" akan selalu sehat dan hebat dalam melakukan aktivitas, seperti yang ditampilkan pada judul berita.

Media advertorial ini tidak ada sub judul yang menjelaskan berita yang sebanyak lima kolom yang ditata rata kiri. Tulisan berita yang menggunakan jenis huruf Arial yang memberikan moto PT Air Mancur, yaitu "quality dan efisiensi", serta kasiat, kandungan, dan manfaat madu. Di samping itu, dalam berita ini diperkenalkan "Madurasa Superman" rasa jeruk dan rasa stroberi sebagai inovasi dan unggulan produk PT Air Mancur yang bekerjasama dengan Warner Bross Entertainment Inc.

Untuk mendukung berita ini ditampilkan dua kemasan primer "Madurasa Superman". Kemasan yang menampilkan gambar Superman terlihat gagah, pemberani, dan patriotik hadir untuk produk merek "Madurasa Superman" sangat menggoda pandangan untuk dilihat. Dua kemesan sachet tersebut mewakili dua rasa, yaitu rasa jeruk dan rasa stroberi. Gambar dua kemesan sachet yang ditempatkan di sisi kanan judul, agar menyatu dengan pesan dan memperjelas pesan dengan bahasa visual. Tampilan gambar kemasan yang ditata satu tegak dan satu lainya miring, memberi kesan hidup dan dinamis.

Advertorial dicetak warna hitam-putih, yaitu tulisan berita warna hitam di atas background warna kertas putih. Tulisan tampak jelas dan mudah dibaca, begitu gambar kemasan produk dangat jelas untuk dilihat. Kejelasan dalam menampilkan gambar dan tipo-grafi yang mudah dibaca merupakan tanda kualitas cetak 
tabloid Aura dengan teknologi tinggi, sehingga detail-detail pada gambar sangat terlihat.

Berita dalam advertorial yang dibuat menjadi lima, agar khalayak lebih mudah membaca dengan santai. Pengaturan kalimat dalam berita yang ditata rata kiri, sebagaimana kita menulis dari kiri ke kanan yang memberi kesan alami, runtun, berita baru, hangat, apa adanya, dan tanpa ada rekayasa. Penataan yang tidak formal mini agar khalayak menanggapinya lebih santai, luwes, dan akrab. Antara judul dengan gambar ada ikatan penglihatan, yaitu bila membaca judul tentu akan melihat gambar. Sebaliknya bila khalayak melihat gambar dua kemasan produk merek "Madurasa Superman" tentu akan membaca judul berita yang berbunyi "sehat hebat Madurasa Superman".

\section{Membidik Kaum Muslim Melalui Berita "Halal"}

Perkembangan industri majalah di Indonesia menunjukkan pertumbuhan yang luar biasa sehingga bisa melayani kebutuhan pendidikan, kesehatan, hukum, ekonomi, hukum, tata boga, hingga hiburan kepada masyarakat berlatar belakang pendidikan dan kelas sosial yang berbeda. Meskipun begitu, secara umum majalah mempunyai ciri-ciri sebagai berikut: (1) Berbentuk lembaran-lembaran cetak yang dijilid berbentuk seperti buku, berisi berita dan informasi secara tematik dan fokus, (2) Menggunakan kertas sampul yang tebal dan mengkilau yang memuat berita utama pada rubrik tertentu dengan dipertegas oleh gambar ilustrasi maupun foto yang menggoda. (3) Beberapa berita yang dihadirkan tetapi lebih luas dalam penyampainya, (4) Diterbitkan lebih banyak berwarna untuk menarik perhatian pembaca, (5) Diterbitkan secara periodik dengan rentang waktu tertentu, misalnya mingguan, dwi mingguan, satu bulanan, dua bulanan, dan sebagainya, (6) Komunikator media ini adalah lembaga atau organisasi, dan perusahaan, dan (7) Target market media ini adalah masyarakat yang mempunyai hobi atau keilmuan sesuai dengan tema yang diambil majalah.

PT Air Mancur sebagai perusahaan jamu terbesar di Solo, mendekatkan produknya kepada sebagian masyarakat berlangganan majalah Ummat. Berita yang diterbitkan harus disesuaikan dengan target market, seperti informasikan mengenai sertifi-kasi kehalalan produk merek "Madurasa" dari Lembaga Pengkajian Pangan, Obat-obatan dan Kosmetika Majelis Ulama Indonesia (LP POM MUI). Pemilihan majalah Ummat berupakan bidikan pasar khususnya masyarakat yang beragama Islam agar mengetahui bahwa produk merek "Madurasa" adalah produk yang halal untuk dikonsumsi.

Dalam membidik pasar harus tepat sasaran bila menginginkan produknya sampai pada konkumen yang membutuhkan. Majalah Ummat yang pembacanya sebagian besar kaum muslim sangat sesuai kalau kehalalan "Madurasa" dipublikasikan pada media tersebut. Strategi promosi ini diperlukan untuk menangkap calon konsumen yang sudah jelas dari segi demografinya. Sebagai contoh berita tentang profil produk yang diterbitkan pada rubrik Pro Halal majalah Ummat. Publikasi yang diterbitkan di majalah Ummat no. 36 Thn IV, 22 Maret 1999/ 4 Zulhijah $1419 \mathrm{H}$, halaman 87 berjudul "Melanjutkan Tradisi Halal" yang menggunakan jenis huruf Century Gothic Bold.

Berita di advertorial diawali dengan hadirnya huruf " $H$ " sebagai inisial "halal" pada pengawal kalimat untuk dibaca. Jenis huruf, ukuran, serta penempatan yang strategis di sudut kiri atas mengajak mata untuk membacanya. Judul "Melanjutkan Tradisi Halal" yang dipertegas dengan sub judul "inilah babak, lanjutkan komitmen halal ala PT Air Mancur, karena berhasil mending-krak omzet, atau ...". Judul dan sub judul yang ditulis dengan huruf Times New Roman secara formal dan simetris. Judul dan sub judul terlihat dan mudah terbaca karena menggunakan huruf berukuran besar bia dibandingkan dengan berita. Di samping itu, judul dan sub judul ditempatkan di sisi atas yang diapit oleh kolom berita di sisi kiri-kanan dan dipertegas 
garis struktural pada gambar. Judul dan sub judul dibuat menarikdan begitu menonjol sehingga orang mau membaca teksnya (Madjadikara, 2004: $35)$.

Advertorial secara verbal, judul dan sub judul menunjukkan bahwa PT Air Mancur selalu memperhatikan konsumen yang sebagian besar beragama Islam. Hal ini telah dibuktikan atas sertifikat halal yang diberikan pada merek "Madurasa". Sub judul sangat menarik karena ada kata "atau,,". Kata ini mempunyai arti konotasi yang beda di setiap pembaca. Namun pada intinya, berita yang ditulis tiga kolom ini mempublikasikan "Madurasa" yang telah mendapatkan sertivikat halal dari Lembaga Pengkajian Pangan, Obat-obatan dan Kosmetika Majelis Ulama Indonesia (LP POM MUI).

Untuk memperjelas secara visual maka ditampilkan gambar beberapa produk dan proses pembuatan "Madurasa". Meskipun pada berita ini ditampilkan gambar warna hitam-putih tapi tampak jelas, seperti gambar proses produksi yang berukuran besar meru-pakan gambar utama yang ditempatkan di tengah-tengah. Di sisi kiri, ditampilkan gambar berbagai produk PT Air Mancur yang sudah mendapatkan sertifikat halal. Agar tidak ada kesalahan persepsi khalayak dalam menginterpretasikan gambar, maka di bawah gambar diberi penjelas bernama caption. Pada caption tertulis "proses produksi madurasa" yang menggunakan jenis huruf Arial Capital, dan "tanggung jawab vertikal (insert) sebagian produk halal itu", yang menggunakan jenis huruf Arial Italic.

Publikasi dibuat menjadi tiga sub berita, yaitu produk akhir, babak kedua, dan tanggung jawab vertikal. Hal ini memudahkan khalayak untuk memilih dalam membaca, mana yang harus didahulukan untuk dibaca. Intinya dalam berita ini dipertegas bahwa PT Air Mancur mempunyai moto "Menuju Kehidupan Yang Lebih Baik" merupakan program sertifikasi halal.

Layout diatur menjadi tiga kolom, pengaturan kalimat rata kiri dan kanan yang memberi kesan rapi, bersih, enak dilihat, dan menarik untuk dibaca. Pengaturan berita menjadi tiga baris atau kolom, merupakan cara memperindah wajah halaman dan agar khalayak tidak cepat lelah dalam membaca. Untuk membatasi tiap berita, dipertegas lagi dengan garis sebagai pemisah kolom sebagai pemercantik layout. Garis diantara kolom merupakan penegas berita, sedangkan garis di sisi atas dan bawah berita merupakan pemercantik, mengekspos berita, dan sebagai ciri khas majalah Ummat. Segmentasi majalah Ummat sebagian besar umat Islam, maka bahasa dalam berita dibuat santun dan lugas yang tidak banyak konotasi. Tampilan yang santun dan rapi sebagai cermin kewibawaan majalah dan menghargai para pembaca.

\section{Kesimpulan}

Simbol merupakan tanda yang melekat pada karya desain advertorial. Media advertorial merupakan karya desain komunikasi visual yang syarat estetika melalui simbol-simbol. Media tersebut mempunyai estetika massa dan estetika pasar melalui citra visual yang dapat dinikmati semua orang. Media yang digunakan sebagai alat informasi berbentuk berita yang mempunyai tugas khusus, yaitu bagaimana pesan yang disampaikan oleh perusahaan selaku produsen sampai pada tujuan ke khalayak (konsumen) melalui simbolsimbol tertentu. Agar berita yang disampaikan dapat dimengerti dan dipahami maka simbolsimbol yang digunakan sesuai dengan sosiokultural masyarakat. Dalam penampilan elemen-elemen desain advertorial disesuaikan dengan kondisi sosial budaya sebagai target market dan target khalayak. Adanya kedekatan sosial budaya berdasarkan simbol-simbol yang ada di masyarakat, maka estetika desain advertorial dapat diterimanya. 


\section{Daftar Pustaka}

Abdullah, Irwan. 2010, Konstruksi dan Reproduksi Kebudayaan, Yogya-karta: Pustaka Pelajar,

Beakley, George C.(1974), Indtroduc-tion Engeneering Design and Graphic, Printed ini the United States of America, America.

Frascara, Jorge. (2004), Communication Design: Principles, Methods, and Practice, Allworth Press, New York.

Geertz, Clifford. (1983), Abangan, Santri, Priyayi dalam Masyarakat Jawa, Pustaka Jaya, Jakarta.

Jefkins, Frank. (1994), Advertising atau Periklanan, terjemahan Haris Mu-nandar. (1997), Erlangga, Jakarta.

Kasali, Rhenald. (1995), Manajemen Periklanan: Konsep dan Aplikasinya di Indonesia, Grafiti, Jakarta.

Lee, Monle \& Carla Johnson. (1993), Principles of Advertising: A Global Perspective atau Prinsip-prinsip Pokok Periklanan dalam Perspektif Global, terjemahan Haris Munandar \& Dudy Priyatna. (2009), Prenada Media Group, Jakarta.

Madjadikara, Agus S. (2004), Bagai-mana Biro Iklan Memproduksi Iklan, Gramedia Pustaka Utama, Jakarta.

Nazsir, Nasrullah. (2009), Teori-teori Sosiologi, Widya Padjajaran, Bandung.

Noth, Winfriend. 1995, Hand Book of Semiotics, America: Indiana Uni-versity Press.

Peraturan Kepala Badan Pengawas Obat dan Makanan Republik Indonesia, No.
HK.03.1.23.07.11.6664 Ta-hun 2011, tentang Pengawasan Kemasan Pangan.

Poerwanto, Hari. 2000, Kebudayaan dan Lingkungan dalam Prespektif Antropologi, Yogyakarta: Pustaka Pelajar.

Rangkuti, Freddy. (2007), Strategi Promosi Kreatif, Gramedia Pustaka Utama, Jakarta.

Ritzer, George. 2009, Sosiologi Ilmu Pengetahuan Berparadigma Ganda, Jakarta: PT. Raja Grafindo Persada.

Ritzer, George. Douglas J. Goodman. 2009, Teori Sosiologi, Yogya-karta: Kreasi Wacana.

Russell, J. Thomas. W. Ronald Lane. (1992), Kleppner's Advertising Procedure (Fifteenth Edition), Prentice Hell, USA.

Suhandang, Kastadi. (2005), Periklanan: Manajemen, Kiat dan Strategi, Nuansa, Bandung

Wistrand, Jhon \& Kranz. (1974), Science \& Tecknology in the Arts, Van Nostrand Reinhold, Melbourne 
JURNAL NOMOSLECA

Volume 2, Nomor 1, April 2016 